\title{
Development in Education Sector in Zandra, Balochistan (Micro Analysis of World System Theory in Anthropological Perspective)
}

\author{
${ }^{1}$ AnwaarMohyuddin, ${ }^{2}$ MamonahAmbreen \\ ${ }^{1}$ Lecturer, Department of Anthropology, Quaid-i-Azam University, Islamabad, Pakistan Mail: PO Box 3060, \\ GPO, Islamabad, Pakistan \\ ${ }^{2}$ Lecturer, DNFCE, Faculty of Education, AllamaIqbal Open University, Islamabad, Pakistan Mail: PO Box \\ 3060, GPO, Islamabad, Pakistan
}

\begin{abstract}
This research paper deals with the process of development in the field of education and the changes taken place in the Village Zandra during the last three decades. Awareness, affordability and marked improvement in educational facilities have caused a general shift of trend towards education. Most of the parents now want their children to finish at least high school and then pursue some technical field.Number of educational facilities and student enrolment has increased in the village. Apart from the basic educational infrastructure the quality, qualification and number of teachers has substantially increased. This study identifies the workings of UN agencies and NGOs working for the promotion of education and how the authoritative core countries extract labour from the peripheral countries and use it in their own benefit causing harmful effects for their education systems. The situation in the village has been analyzed in light of world system theory. This research was conducted in Village Zandra District Ziarat. Qualitative anthropological techniques were used to collect emperical data.
\end{abstract}

Key Words: core, periphery, underdevelopment, capital accumulation, socialization

\section{Introduction}

In the past people used to have their own indigenous traditional system of acquisition of knowledge about different things including how to treat themselves, their children and even their animals in illness, how to grow different crops etc. However in per-industrial society, people acquired the required knowledge and skills through an informal socialization process which includes ordinary everyday contacts with parents and other kin. As industry was established and developed, the need of mass schooling was felt. As a result knowledge spread rapidly, the pace of social change increased and many new economic roles were created. Members of a modern industrial society need specialized knowledge and skills, if they are to play their adult roles effectively. All modern societies recognize that learning of such knowledge and skills cannot be left on chance. It requires lengthy attendance at specialized formal organization such as elementary schools, high schools, colleges and universities. In all industrial societies, education is a central social institution. Education can be taken as synonymous to socialization, as both processes involve transmission of culture from one person or group to another. The distinguishing feature of education in modern industrial societies, however, is that it has become an institutionalized, formal activity. Modern societies deliberately organize the educational experience, make it compulsory for people in certain age groups, train specialists to act as educators, and provide locations and equipment for the teaching and learning process. For our present purpose, education is systematic, formalized transmission of knowledge, skills and values.

Even today, uneducated people have their own knowledge system which supports their lifestyle and satisfy their basic needs. The present educational system actually supports industry directly or indirectly. It teaches us how to serve the industry. After getting education we abandon our traditional way of life and move towards technology. We often try to find job, implying that in one way or the other, we are serving the industry. Ultimately education is producing the skilled labour for industry. Migration to urban areas is also an indirect support of education to the industry, which changes consumption patterns of the people who have become more dependent on machine made products.

\section{Locale Of Study}

The present research was conducted in Village Zandra, District Ziarat, in Baluchistan, Pakistan. Area wise Baluchistan is the largest province of Pakistan. It shares its northern border with Afghanistan with major cities of Chagai, Quetta and Zhob. The western border is shared with Iran via districts Makran and Kharan. The eastern end is bounded by the Sind province, whereas the Arabian Sea lies on its south. 
The Village Zandra is situated $108 \mathrm{~km}$ southeast of Quetta just $12 \mathrm{~km}$ short of Ziarat town. The village is $8,000 \mathrm{ft}$. above sea level and is surrounded by grey hills, apple orchards and Juniper forest, which is considered to be the $2^{\text {nd }}$ largest in the world. Total population of Zandra according to a census carried out in 1986-87 was 2,734 residing in 120. However, according to the survey conducted by the researcher in 2007 the total population had only increased marginally to 3,234 consisting of 295 houses.

\section{Research Methodology}

Methodology of the current research was based upon qualitative anthropological research methods. Methodology means philosophy of the research process which includes the assumptions and values that serve as a rationale for research and the standards or criteria the research use for interpreting data and reaching conclusions. Whereas by "method" we simply mean the research technique or tool used to gather data. The methods used for this research include socio-economic survey, participant observation, key informant interviews, interviews, case studies and focus group discussions. For socio-economic survey 100 households were selected through simple random sample. We choose two key informants in the village on our personal judgment basis, which knew most of the people in the village and their socio-economic conditions. Participant observation was used in order to get first hand and accurate information about the respondents. We participated in the daily activities of the village. In-depth interviews were conducted with the elder members of society to get detailed information. Structured Interviews were used to collect information from the teachers and other working women because they take the interview more seriously and give reasonably accurate answers. Case studies were conducted to get a detailed presentation of data related to different events. This research was a longitudinal study. First of all a 4 months visit was conducted in 1987, then a couple of month long visits in 1990s and finally in 2007.

\section{Theoretical Framework}

This research paper would explore the application of world systems analysis to the education systems. The interactions between global economic and cultural forces and local contexts would also be taken into account in the field of education. Special attention would also be given to the impact of major governmental as well as nongovernmental organizations on education policy makers.

In the late 1960s to early 1970s two major approaches appear in world systems theory. One is based on Marx's work on the international capitalist system, starting with Gunder Frank's dependency theories (1969), Cardoso and Falleto (1969), Santos (1970b), Rodney (1974), Samir Amin (1970) (1973) and the major contributor ImanuelWallerstein(1974) (1980) (1989). This approach is called as "realist approach" of world systems theorist. The other approach is "neoinstitutionalist approach" based upon the works of John W. Meyer, a sociologist from Stanford and his student Robert Arnove (1980) on the establishment and expansion of schooling around the world. They used world systems analysis as the necessary framework in the field of comparative and international education to understand trends in educational around the world, focusing on curriculum reform, language of instruction, and the outcomes.

Meyer (1971) explained the factors involved in the expansion of educational systems at global level. Meyer and Hannan (1979) in their work "National Development and the World System: Educational, Economic, and Political Change, 1950-1970", emphasized the need to analyze educational expansion in the light of world systems analysis. They speculated that the characteristics of the contemporary world system are causing this expansion and simultaneously affecting all nations. Meyer et al (1992) traced the norms and ideology of social and personal development and spread of compulsory schooling all over the world in Latin Christendom Enlightenment project. They consider formal schooling systems as a universalistic ideology, where the religious concepts were replaced by economic growth and human resource development following the Western model.

Neoinstitutionalist perspective says that the formation of schooling systems and the development of nations with their citizens should be based upon widely spread and deep routed world norms and expectations. They think that without getting full membership of the world community you are not entitled for human rights, state-protected citizen rights, and democratic forms. This assumption was challenged by "realist" approach of world systems theorist (Wallerstein, 2000; Frank, 1969; Cardoso and Falleto, 1969). According to them reason for underdevelopment of peripheral countries in the world economy is not the lack of economic and human resources, it is due to an unequal relationships between them and the core regions. As long as this unequal exchange of goods prevails between the core and peripheral countries the periphery is likely to stay underdeveloped. Meyer and his fellow theorists while conducting their research on the functionality of a global culture were very much focused on educational systems. Though Wallerstein's work was criticized by Sklair (1999) for over focusing on economy and nation-states while studying world system, his approach to the world system as the unit of analysis was used to understand comparative and international education by Arnove (1980) in his essay published in the Comparative Education Review wherein he used slightly different approach from the institutionalists by focusing on mechanism and results of the organizations working for the promotion and 
expansion of education and sometimes imposing their own educational policies and agendas.Initially Meyer and Hannan (1979), briefly discussed about the inequalities between the countries and later Ramirez, Boli and Thomas (1997) have discussed the workings of UN agencies and NGOs working for the promotion of education. They documented how these authoritative core countries extract labour from the peripheral countries and use it in their own benefit causing harmful effects for their education systems. Schooling in peripheral countries supports the process of capital accumulation for the core regions, rather than serving the interests of their own populations.

Arnove $(1980,2003)$ supported the realists' point of view. He argued that the international agencies providing financial and technical support to the universities and research institutions were actually developing policies and relationships that were beneficial to the core countries, not to the peripheral recipients of aid. Mundy and Lynn (2001) have mentioned that the international agencies from core countries have started providing financial and technical assistance in the field of education to the peripheral countries through NGOs. Sutton and Arnove (2004) pointed out certain issues related to this reliance on NGOs. They questioned that did the NGOs providing educational services reduce the pressure from the government? Did they deteriorate the authority of state in setting the goals and syllabus for the schools? Did they understand local needs and showed some flexibility to solve them? Did they hold moral and legitimate authority? What were the consequences of this donor and NGO relationship? Was there any negative feature like sponsorship, favoritism, and corruption associated with them? And above all whom they were serving, states or international donors?

\section{Results And Discussion}

The literacy rate in the village is $16.78 \%$. It is $24.53 \%$ among the males and $6.90 \%$ among female. Some major changes have taken place in the field of education sector over the last 3 decades. The educational facilities are available in the village both for boys and girls in governmental, non-governmental and private sector up to secondary and elementary levels respectively. Madressas (religious educational institution) and the private tuition centre are also present in the village. For the higher education people send their sons to the colleges and universities in Quetta. In 1980 the village only had one primary school for girls, a middle school for girls and boys and two madrasssas. However, with a joint effort of the government, NGOs and public sector, the number of schools, madrasssas and tuition centres have been increased to 14. In 1980's a single matric pass teacher was working as the principle of the only existing girls' primary school, graduates are now teaching at this facility. Similarly the boys' schools now have three masters' qualified teachers as opposed to a single graduate in 1980 . Thus the overall educational facilities and quality of education has substantially increased in the Zandra village from 1980s onwards.

Awareness has also been created among the parents regarding their children's education especially the girls. The first major change is an increase in the enrolment in schools. In mid 1980s, it was 20 to 25 students in boys' schools while 15 to 20 in girls' schools, but now it increased up to 35 to 40 in boys', and 25 to 30 in girls' schools. The dropout rate has been decreased $50 \%$ to $33 \%$ which still is very high but improvement is there. In 1980 s only half of them were reaching at the primary level, but now it is about $66 \%$. It is mainly because majority of the parents were less educated and could not provide necessary support and motivation to their children. Now the literacy rate has increased and the parents are in better position to teach their children at home.The reasons for increase in enrolment and overall literacy level are quoted differently by different classes. For upper class, it is awareness, for middle, it is affordability, while for lower class, it is the motivation for additional source of income in future.

The second change during the period under reference is the level of awareness among parents. People are today more conscious about their children's education. Most of them are pushing their children, both boys and girls to the higher level, and for that purpose 81 families of the village have migrated to Quetta and other big cities. Male heads of some families are still working in the village but their families are living in Quetta, and they visit their families on weekends. There are another 26 families who have not shifted to Quetta but have constructed houses over there where any of their adult male family member lives. The rest of the family members can go and live there whenever needed. For example, the children could be sent there for their higher education. The ladies go and live there for their deliveries.This migration has supported the cause of education. Now the people are in a position to provide better educational facilities to the children. One of these migrated families had three daughters and all of them are MBBS doctors and practicing in Quetta. If we see this relationship of migration and education from a different angle, we can say that education has become a cause of urban migration, which resulted into breakdown of joint family system.In the village joint families are turning into nuclear families, and education is the main factor behind it. The educated ladies do not adjust with uneducated ladies in the family. They want to socialize their children the way they like and do not tolerate interference of others. These ladies also do not contribute to household works, leading to unrest among other ladies of the family, which ultimately results into breakup of the family. 
The attitudes regarding the gender discrimination in the field of education has also changed. Initially the main reason for not sending their daughters to schools was pardah but now more of the economic reasons were reported. Some people are still reluctant to invest on their daughters because they are not permanent members of the family and mostly they do not contribute in the household economy even if they are working. Most of the parents say that we do not have to send them for jobs so why to educate them because the males who send their females for jobs face a bad reputation in the society. Economic dependence on females was considered as shamelessness (baygharity). This concept was and still is a barrier for the girls in access to education but there is a notable change in it. The people who educate and allow their daughters to work have a different argument. They say that there is nothing wrong in depending economically on females because the people have been doing it since a long time. The ladies have always been working in the fields with the males which is an indirect economic contribution and the male has been enjoying it since forever. So there is no harm in sending the female to work.Above discussion makes it clear that economy is the main feature behind all types of gender discrimination including education, food, preference, inheritence etc. More investment is made on sons believing them as permanent members of the families as well as the earning hands. As girls have to go to the other family. Delayed marriages of some educated working women were also observed, as the parents do not want to lose an earning member of the family so early as the invester wants the maximum benefit of his investment for himself not for the others.

As education enables a person to put a question, people do not give education to their daughters fearing that they would demand their right of inheritance. Here, thus, again economy plays a role in keeping the girls away from the school.Better food is served to the boys to build them stronger for working heard and earning money. So the sons are preferred in giving food for economic benefits. Economy, thus, becomes the major player in gender discrimination. The today's materialistic life has created more demand for money, increasing discrimination against women. Some changes in schooling systems and their syllabuses were also observed during last 10 years. NGOs have been introduced in the village, which provide educational services. English medium school has been introduced in the village. In government schools English as a subject starts from class 6 and in schools supported by NGOs start teaching English right from grade one. As far as syllabus is concerned science subject have been introduced in madressa as compulsory for all. In schools major changes have been made in Islamic studies' syllabus. Arabic was taught as a compulsory subject, which has been made optional now. Music was never taught in schools as it never was a part of local culture, but now it has become compulsory. Music teachers have been hired in all schools owned by Government as well as NGOs. Socialization is provided to the students following the western style. The natives studying in NGO sponsored schools in Southern Punjab reported such academic activities where the children are encouraged to call the police against their parents if they ever punish them or even stop them from doing anything. This type of children's attitude never was a part of their culture.

The following discourse further analyzes this situation by linking it to the conceptual and theoretical concepts.

- In per-industrial society, people acquired the required knowledge and skills through an informal socialization. After the establishment of industry, the need of mass schooling was felt to impart specialized knowledge and skills for smooth running of industry. So this schooling system provides skilled labour to the industry. Core countries are providing financial assistance mostly through NGOs to the periphery so that they could get skilled labour at cheaper rates and to keep the labour rates low they do not provide any real chance for economic growth to these countries as the development of capitalism in core countries requires a continuous and conscious underdevelopment of peripheral countries for regular supply of raw materials and cheap labour. They just keep them revolving in a vicious circle which starts from poverty leads to the dependency on core countries from where they get low wage rates which ultimately increases poverty. Secondly the consumption patterns of educated families change. Their reliance on consumer products increases. So it benefits the industry both ways.

- People's perception of education as a job seeking instrument is a result of awareness campaigns launched in peripheral regions by the core countries to ensure a regular supply of inexpensive labour. The educated youth in peripheral countries only looks for direct or indirect employment in the industrial sector benefiting the core countries.

- Education can be taken as synonymous to socialization. Core countries control the labour in periphery through socialization. They introduce the syllabus and the medium of education of their choice so that they could create and maintain a pool of less expensive human resource. Changes in schooling systems, syllabuses and other academic activities were evident in the village.

- Education ultimately leads to urban as well as overseas migration. Actually both these phenomena support each other. It becomes difficult for the educated people to live in the villages as there are less resources and facilities. On the other hand urban migration provides better educational facilities to the people. So education leading to urban and overseas migration serves the purpose of core countries as it 
has been discussed in the previous chapter. Thomas S. Popkewitz from Department of Curriculum \& Instruction, University of Wisconsin-Madison USA while addressing in National Curriculum conference of USAID Teacher Education Project (Pre-STEP) held in Islamabad said,

"We do not invest much on education in our country. We do not even motivate our youth to get professional education in specific fields or even to complete their basic education up to graduate level because we can attract skilled human resource from third world at lower rates. We have the resources and can provide them what they cannot get in their own countries." (2012).Keeping the peripheral countries at status quo helps the core countries in their brain drain programme.

The above discussion support the concept of world system theory where the theorists Meyer (1971, 1992), Hannan (1979), Ramirez, Boli and Thomas (1997), Arnove (1980, 2003 Mundy and Lynn (2001), and Sutton (2004)have pointed out the intervention of core regions in the educational sector of the peripheral countries through financial assistance to the NGOs and pressurizing the Governments in certain cases.

\section{Conclusion}

Man is change oriented by nature. He has always been striving for the richness of human life.IndustrialRevolution has changed the concept from richness of human life to the richness of the economy in which a man lives. Considerable progress has been made in human life in the past. Most the people are living healthier and a longer life. They are better educated and have a greater access to consumable products and services. During last few decades the pace of the development has really been increased. Even the economically poor peripheral countries are giving great importance to people's income resources, health and education.

According to world system theory core countries have an interest in growth of the peripheral countries, because such a growth increases demand for the goods produced by the capitalist industry. This, in turn, will promote growth in the core countries. The world's capitalist economies determine the rout for development of the large part of the world's population in their own favour. The economically backward countries have to pledge considerable resources to set in motion with industrial development process.

Core countries are actually controlling the peripheral countries through their educational systems. They are creating such type of awareness among the masses in peripheral regions which ensures a regular supply of inexpensive labour and raw materials, and enhances the consumption of the consumable products. Introducing the syllabus and the medium of education of their choice also helps them a better control in the underdeveloped world.

In the end the researcher is in full agreement with the views of world system theorists who have been working in the field of capitalist world economy (Wallerstein, Samir Amin, and A. G. Frank), as well as comparative education (Meyer,Arnoveand Ramirez). In the light of empirical data world system theory is found valid and accepted.

\section{Bibliography}

[1] Amin, S. (1970). L'accumulation à l'échellemondiale; critique de la théorie du sous-développement. Dakar: IFAN.

[2] Amin, S. (1973). Neo-colonialism in West Africa.Hamondsworth, UK: Penguin.

[3] Arnove R. F. (1980). Comparative Education and World-Systems: Comparative Education Review, Vol. 24, No. 1, 48-62.

[4] Arnove, R. F. (2003). Reframing Comparative Education. In R. F. Arnove\&C. A. Torres (Eds.), Comparative Education: The dialectic of the global and the local (2nd ed., pp. 1-23). Lanham, MD: Rowman\&Littlefield.

[5] Boli, J., Ramirez, F. O., \& Thomas, G. M. (1997). World culture in the world polity: A century of institutional non-governmental organization. American Sociological Review, 62, 171-190.

[6] Cardoso, F. H\&Falletto, E. (1969). Dependenciaydesarollo en América Latina. Mexico City: SigloVentiuno.

[7] Dos Santos, T. (1970b). The Structure of Dependency. American Economic Review, 60(2), 231-236.

[8] Frank, G. (1969). Capitalism and Underdevelopment in Latin America. New York: Monthly Review Press.

[9] Meyer, J. W. (1971). Economic and Political Effects on National Educational Enrollment Patterns. Comparative Education Review, $15,28-43$.

[10] Meyer, J. W. \&Hannan, M. T. (1979).Introduction. In J. W. Meyer and M. T. Hannan (Eds.), National development and the world system: Educational, economic, and political change, 1950-1970 (pp. 3-16). Chicago, IL: University of Chicago Press.

[11] Meyer, J. W., Boli, J., Thomas, G. M. \& Ramirez, F. O. (1992).World Society and the Nation-State.American Journal of Sociology, 103, 144-181.

[12] Rodney, W. (1974). How Europe Underdeveloped Africa. Washington, DC: Howard University Press.

[13] Mundy, K. \& Murphy, L. (2001). Transnational advocacy, global civil society?: Emerging evidence from the field of education. Comparative Education Review, 45, 85-126.

[14] Popkewitz, T. S. (2012). Lecture in National Curriculum Conference of USAID Teacher Education Project (Pre-STEP), Islamabad.

[15] Sklair, L. (1999). Competing conceptions of globalization. Journal of World Systems Research, 5 (2), 143-162.

[16] Sutton, M. \&Arnove, R. F. (Eds.). (2004). Civil society or shadow state? State/NGOs relations in Education. Greenwich, CT: Information Age Publishing.

[17] Wallerstein, I. (1974). The modern world system, vol. I: Capitalist agriculture and the origins of the European world economy in the sixteenth century. New York: Academic Press.

[18] Wallerstein, I. (1980). The Modern World System II: Mercantilism and the Consolidation of the European World Economy. 1600-1750. New York: Academic Press.

[19] Wallerstein, I. (1989). The modern world system, vol. III: The second great expansion of the capitalist world economy 1730-1840s. San Diego: Academic Press.

[20] Wallerstein, I. (2000). The Development of an Intellectual Position: Adapted version of the introductory essay to the essential Wallerstein. New York: New Press. 